\title{
Optimal Treatment using Statins from Childhood in Heterozygous Familial Hypercholesterolemia
}

\author{
Atsushi Nohara \\ Department of Advanced Research in Community Medicine, Kanazawa University Graduate School of Medical Sciences, Kanazawa, \\ Japan
}

\section{See article vol. 23: 48-55}

Familial hypercholesterolemia (FH) is "underdiagnosed and undertreated" and a very common inherited disease. Most FH patients are not appropriately diagnosed and this is a reason why they are not treated intensively ${ }^{1)}$. Premature coronary artery disease (CAD) remains a menace to the patients with $\mathrm{FH}$ even in this era of strong statins. All adult patients with FH should be intensively treated using high-dose statins, but lowdensity lipoprotein (LDL)-lowering effects of conventional drugs including strong statins are not enough for many FH patients after their cardiovascular events. This is the second reason of "undertreatment". There is an urgent need to prevent early deaths due to premature coronary artery disease in $\mathrm{FH}$.

Secondary prevention is more difficult than primary prevention. Lowering LDL-C levels to the "normal" range during childhood is more feasible and reliable for reducing the lifetime CAD risk than lowering the levels to $<100$ or $70 \mathrm{mg} / \mathrm{dL}$ in adult $\mathrm{FH}$ patients with established atherosclerosis. PCSK9 monoclonal antibodies have recently been developed with remarkable efficacy and considerable safety in clinical stud$\mathrm{ies}^{2)}$, but even with this class of drugs, established atherosclerosis should be irreversible. Early identification is essential to prevent early deaths, and children belonging to $\mathrm{FH}$ families should undergo a screening before the age of 10 years ${ }^{3)}$.

It has been hypothesized that atherosclerosis starts in childhood. Clinical studies such as the PDAY study or the Bogalusa Heart Study have demonstrated that dyslipidemia in youth clearly accelerates early ath-

Address for correspondence: Atsushi Nohara, Department of Advanced Research in Community Medicine, Kanazawa University Graduate School of Medical Sciences, Kanazawa, Japan

E-mail: a-nohara@med.kanazawa-u.ac.jp

Received: August 24, 2015

Accepted for publication: August 27, 2015 erosclerotic changes in the carotid artery, aorta, and coronary artery ${ }^{4,5)}$. Analysis of carotid intima-media thickness (cIMT) has shown that increased cIMT is already evident at the age of 7 years in children with $\mathrm{FH}^{6}$. Elevated cholesterol levels early in life accelerate the development of CAD during adulthood, and lowering the levels in children and adolescents must be beneficial in $\mathrm{FH}$.

The cumulative "LDL-C burden" model, in which LDL-C burden $=$ sum of LDL-C levels $\times$ years of age, has been recently focused on; the model should be translated as a threshold for $\mathrm{CAD}^{7)}$, based on the data from the Dutch FH register. The early initiation of low-dose statins could be more beneficial than a late initiation of high-dose statins for FH heterozygotes. For example, low-dose statins initiated at 10 years of age have an advantage over high-dose statins initiated at 18 years of age as per this model (Fig. 1).

Which drug should be the first-choice in children with FH? Bile acid-binding resins had been the first choice for children because of their established safety; they exerted their effects only in the intestinal lumen and did not have any systemic effects. In USA, NECEP recommended bile acid-binding resins in $1992^{8)}$. Japanese Guideline has recommended resins so far based on its safety ${ }^{9,10)}$. On the other hand, resins have limited effects on LDL-C lowering and limited evidence for CAD prevention compared with statins. The American Heart Association has decided to recommend statins for children with $\mathrm{FH}$ in $2006^{11}$, and now many guidelines recommend statins for children and adolescents with FH (Table 1).

It should be mentioned that many guidelines recommend drug therapy after lifestyle modification approximately at 6-12 months. Sometimes, lipid levels fluctuate widely during puberty. On the other hand, lifestyle interventions are important, but alone are insufficient in $\mathrm{FH}$.

In their article, published in the present issue, Harada-Shiba et al. report the efficacy and safety of pitavastatin in Japanese male children with $\mathrm{FH}^{12)}$. 


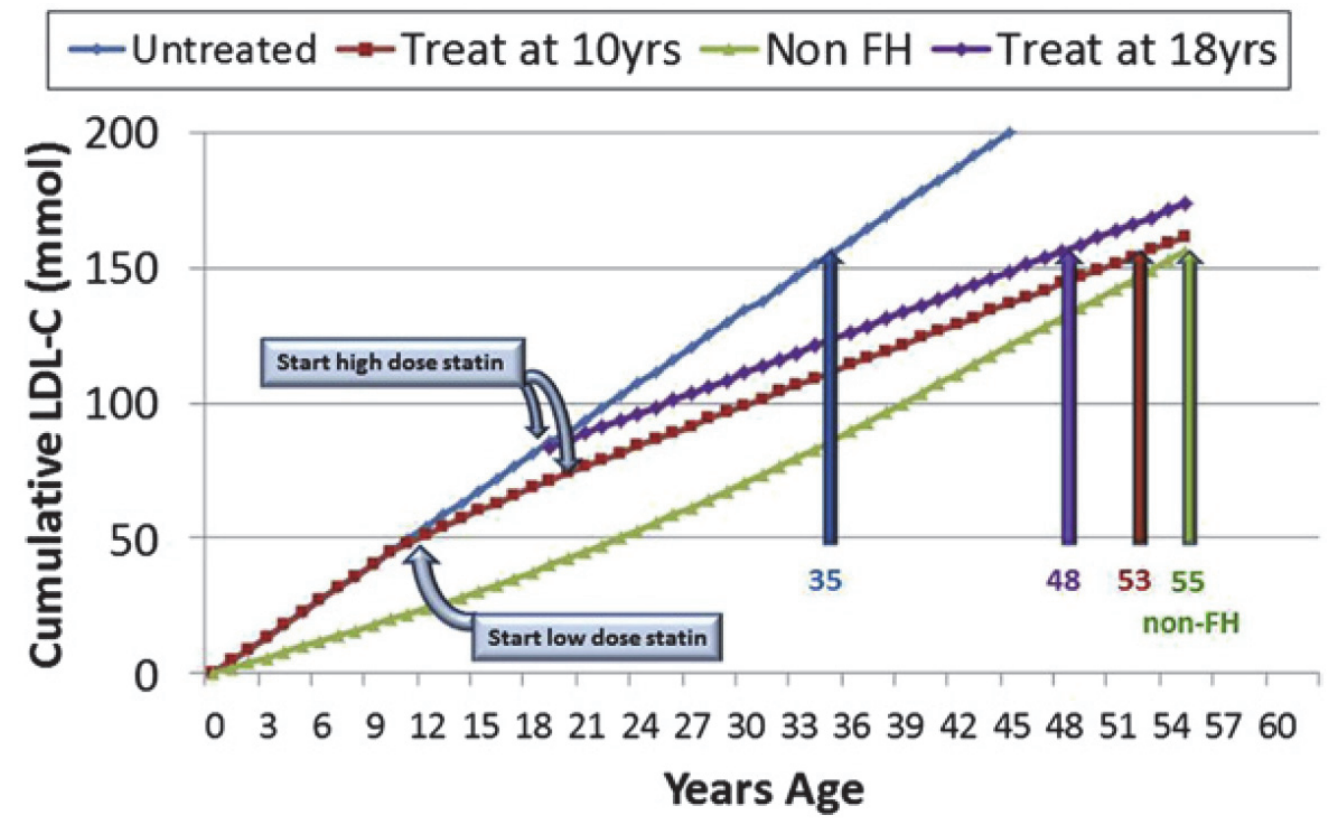

Fig. 1. LDL-C burden in non-FH and FH subjects depending on different age groups of starting statin therapy ${ }^{7}$. The cumulative LDL-C burden of a 55 year old non-FH patient is 160 $\mathrm{mmol}$, and it has been reached by an untreated-FH patient by the age of 35 years, by an FH patient treated since age 18 years by the age of 48 years, and by an FH patient treated since age of 10 years by the age of 53 years.

Pitavastatin moderately safely reduced LDL-C levels in these children.

It is noteworthy that no statin had been approved for children in Japan before, and all statins were prescribed for children as off-label use. Although doctors had been able to prescribe statins for children as offlabel use, needless to say, official approval is desirable. In the USA and Europe, simvastatin, lovastatin, atorvastatin, pravastatin, fluvastatin, and rosuvastatin have been approved for use in children with FH. In Australia, pravastatin, simvastatin, and fluvastatin have been licensed for children. Now, Livalo® (pitavastatin) has become a sole approved statin for children with $\mathrm{FH}$ in Japan with the data of this study. Generic pitavastatin is still off-label for children with FH in Japan officially.

Concerns of adverse effects with statin use in children have been discussed for many years, because children are not miniature adults. One concern of statin use in children is hormonal changes. The guidelines recommend monitoring the physical and sexual development, although repeated short-term have reported showed very small effects in hormonal changes ${ }^{13)}$. In addition, the potential effect on the central nervous system has been discussed, and most approved statins are licensed for children $>8-10$ years of age. Statins are contraindicated for pregnant and nursing women, and all young females with $\mathrm{FH}$ are recommended to receive pre-pregnancy counseling. The guidelines recommend the use of oral contraceptives, if indicated. Clinicians also should be aware of the possibility of fetal complication in accidental pregnancy while taking statins, which has been reported to be relatively less ${ }^{14)}$.

Should boys and girls start treatment at similar ages? The cardiovascular events of female heterozygous $\mathrm{FH}$ in the second or third decades are much rare compared with male FH. However, most young females with FH must stop taking statins at least several years in total before planned conception and during pregnancy and nursing. Recent guidelines recommend similar age for starting medications taking into account female disadvantage in LDL-C burden ${ }^{3,15)}$. Recent paper reported that CHD mortality rates in young females (aged $<55$ years) demonstrated no improvements in contrast to dramatic decline in older males or females during three decades ${ }^{16)}$. Generally, young females have been left behind in CVD prevention, but young female with $\mathrm{FH}$ should be one of the highest CVD risk groups even if occurring later in life than in males.

We should be aware of the limitations of the data 
Table 1. Summary of the Drug Recommendations in Guidelines for Children and Adolescents with Heterozygous FH ${ }^{1,3,8,11,18-23)}$

\begin{tabular}{|c|c|c|c|c|c|}
\hline $\begin{array}{l}\text { Area } \\
\text { (year) }\end{array}$ & $\begin{array}{l}\text { Guideline committee/ } \\
\text { Academic society }\end{array}$ & $\begin{array}{l}\text { Medication considered after } \\
\text { adequate diet-therapy in }\end{array}$ & $\begin{array}{l}\text { First-choice } \\
\text { drug }\end{array}$ & $\begin{array}{l}\text { Initial LDL-C } \\
\text { targets }\end{array}$ & Ref. \\
\hline $\begin{array}{l}\text { USA } \\
(1992)\end{array}$ & $\begin{array}{l}\text { NCEP Expert Panel on Blood } \\
\text { Cholesterol Levels in Children } \\
\text { and Adolescents }\end{array}$ & $\begin{array}{l}\text { Age } \geq 10 \text { years and } \\
\text { LDL-C } \geq 190 \text {, or } \\
>160 \mathrm{mg} / \mathrm{dL} \text { with } \\
\text { additional CVD risks* }\end{array}$ & $\begin{array}{l}\text { Bile acid- } \\
\text { binding resins }\end{array}$ & - & 8 \\
\hline $\begin{array}{l}\text { USA } \\
(2006)\end{array}$ & American Heart Association & $\begin{array}{l}\text { Age } \geq 10 \text { years in males and } \\
\text { after menarche in females, and } \\
\text { LDL-C } \geq 130 \mathrm{mg} / \mathrm{dL}\end{array}$ & Statins & LDL-C $<130 \mathrm{mg} / \mathrm{dL}$ & 11 \\
\hline $\begin{array}{l}\text { USA } \\
(2007)\end{array}$ & American Heart Association & $\begin{array}{l}\text { Age } \geq 10 \text { years in males and } \\
\text { after menarche in females, and } \\
\text { LDL-C } \geq 190 \text {, or }>160 \mathrm{mg} / \mathrm{dL} \\
\text { with additional CVD risks* }\end{array}$ & Statins & $\begin{array}{c}\text { Minimal, } \\
\text { LDL-C }<130 \mathrm{mg} / \mathrm{dL} \\
\text { Ideal, } \\
\text { LDL-C }<110 \mathrm{mg} / \mathrm{dL}\end{array}$ & 18 \\
\hline $\begin{array}{l}\text { USA } \\
(2008)\end{array}$ & $\begin{array}{l}\text { American Academy of } \\
\text { Pediatrics }\end{array}$ & $\begin{array}{l}\text { Age } \geq 8 \text { years, and LDL-C }>190 \text {, } \\
\text { or }>160 \mathrm{mg} / \mathrm{dL} \text { with additional } \\
\text { CVD risks* }\end{array}$ & Statins & $\begin{array}{l}\text { LDL-C }<160 \mathrm{mg} / \mathrm{dL} \\
(110-130 \mathrm{mg} / \mathrm{dL} \text { in } \\
\text { high-risk group })\end{array}$ & 19 \\
\hline $\begin{array}{l}\text { UK } \\
(2008)\end{array}$ & $\begin{array}{l}\text { National Institute for Health } \\
\text { and Clinical Excellence }\end{array}$ & $\begin{array}{l}\text { Usually by the age of } 10 \text { years } \\
\text { with proven FH }\end{array}$ & Statins & - & 20 \\
\hline $\begin{array}{l}\text { Australia } \\
(2011)\end{array}$ & $\begin{array}{l}\text { Australian Atherosclerosis } \\
\text { Society }\end{array}$ & $\begin{array}{l}\text { Age } \geq 10 \text { years in males and } \\
\text { after menarche in females. }\end{array}$ & Statins & $\begin{array}{c}\text { Intermediate risk: } \\
\text { LDL-C }<155 \mathrm{mg} / \mathrm{dL} \\
\text { High risk: } \\
\text { LDL-C }<116 \mathrm{mg} / \mathrm{dL}\end{array}$ & 21 \\
\hline $\begin{array}{l}\text { USA } \\
(2011)\end{array}$ & $\begin{array}{l}\text { American Academy of } \\
\text { Pediatrics }\end{array}$ & $\begin{array}{l}\text { Age } \geq 10 \text { years and } \mathrm{LDL}-\mathrm{C} \geq 190 \\
\text { or } \geq 160 \mathrm{mg} / \mathrm{dL} \text { with additional } \\
\text { CVD risks }\end{array}$ & Statins & LDL-C $<130 \mathrm{mg} / \mathrm{dL}$ & 22 \\
\hline $\begin{array}{l}\text { USA } \\
(2011)\end{array}$ & $\begin{array}{l}\text { National Lipid Association } \\
\text { Expert Panel on Familial } \\
\text { Hypercholesterolemia }\end{array}$ & Age $\geq 8$ years and LDL-C $\geq 190$ & Statins & $\begin{array}{l}50 \% \text { reduction in } \mathrm{LDL}-\mathrm{C} \\
\text { or } \mathrm{LDL}-\mathrm{C}<130 \mathrm{mg} / \mathrm{dL} \text {. }\end{array}$ & 23 \\
\hline $\begin{array}{l}\text { Japan } \\
(2012)\end{array}$ & Japan Atherosclerosis Society & $\begin{array}{l}\text { Age } \geq 8-10 \text { years in males and } \\
\text { after menarche in females, and } \\
\text { LDL-C } \geq 190 \text {, or } \geq 160 \mathrm{mg} / \mathrm{dL} \\
\text { with additional CVD risks* }\end{array}$ & $\begin{array}{l}\text { Bile acid- } \\
\text { binding resins }\end{array}$ & - & 9,10 \\
\hline $\begin{array}{l}\text { Europe } \\
(2013)\end{array}$ & $\begin{array}{l}\text { European Atherosclerosis } \\
\text { Society }\end{array}$ & $\begin{array}{l}\text { Age } \geq 8-10 \text { years with } \\
\text { proven } \mathrm{FH}\end{array}$ & Statins & $\mathrm{LDL}-\mathrm{C}<135 \mathrm{mg} / \mathrm{dL}$ & 1 \\
\hline $\begin{array}{l}\text { Global } \\
(2014)\end{array}$ & International FH Foundation & $\begin{array}{l}\text { Age } \geq 8-10 \text { years with } \\
\text { proven } \mathrm{FH}\end{array}$ & Statins & $\begin{array}{c}\text { Age of } 8 \text { and } 10 \text { years: } \\
\text { LDL-C }<155 \mathrm{mg} / \mathrm{dL} \\
\text { Age }>10 \text { years: } \\
\text { LDL-C }<135 \mathrm{mg} / \mathrm{dL}\end{array}$ & 3 \\
\hline
\end{tabular}

* Family history of premature CAD in first-degree relatives or additional risk factors. Please refer to original articles for details.

available at present. It is difficult to discuss the absolute CAD events during childhood, and studies have shown the benefit of drug interventions are based on surrogate markers such as cIMT ${ }^{17)}$. However, it is not ethically realistic to conduct a randomized controlled study from childhood until the age when CAD frequently occurs. In addition, it is still uncertain that the concept of LDL-C burden model can be applied equally to boys and girls. Moreover, long-term safety data on physical and sexual development including fertility is not currently sufficient. Some increase has been noted in the risk of diabetes on using statins in adults, but data is limited in children. Prospective data must be carefully collected from childhood on the long-term safety.

Optimal treatment with statins since childhood 
is a feasible and promising strategy to prevent early cardiac deaths in patients with $\mathrm{FH}$. The early initiation of statins can result in almost normalized CAD risk throughout their life. Although there is some unresolved safety concerns, there are no obvious harmful evidence overwhelming expected benefits till date. We should judge the balance between the merits and demerits of the early initiation of statins in young $\mathrm{FH}$.

\section{Conflicts of Interest}

Dr. Nohara

Sanofi - Research Grants

MSD - Research Grants

Shionogi - Research Grants

Kowa - Research Grants

Astellas - Research Grants

Aegerion - Research Grants

Astra-Zeneca - Research Grants

\section{References}

1) Nordestgaard BG, Chapman MJ, Humphries SE, Ginsberg HN, Masana L, Descamps OS, Wiklund O, Hegele RA, Raal FJ, Defesche JC, Wiegman A, Santos RD, Watts GF, Parhofer KG, Hovingh GK, Kovanen PT, Boileau C, Averna M, Boren J, Bruckert E, Catapano AL, Kuivenhoven JA, Pajukanta P, Ray K, Stalenhoef AF, Stroes E, Taskinen MR, Tybjaerg-Hansen A and European Atherosclerosis Society Consensus P. Familial hypercholesterolaemia is underdiagnosed and undertreated in the general population: guidance for clinicians to prevent coronary heart disease: consensus statement of the European Atherosclerosis Society. Eur Heart J. 2013; 34: 3478-3490a

2) Mabuchi $\mathrm{H}$ and Nohara A. Therapy: PCSK9 inhibitors for treating familial hypercholesterolaemia. Nature reviews Endocrinology. 2015; 11: 8-9

3) Watts GF, Gidding S, Wierzbicki AS, Toth PP, Alonso R, Brown WV, Bruckert E, Defesche J, Lin KK, Livingston M, Mata P, Parhofer KG, Raal FJ, Santos RD, Sijbrands EJ, Simpson WG, Sullivan DR, Susekov AV, Tomlinson B, Wiegman A, Yamashita S and Kastelein JJ. Integrated guidance on the care of familial hypercholesterolaemia from the International FH Foundation. Int J Cardiol. 2014; 171: 309-325

4) Newman WP, 3rd, Freedman DS, Voors AW, Gard PD, Srinivasan SR, Cresanta JL, Williamson GD, Webber LS and Berenson GS. Relation of serum lipoprotein levels and systolic blood pressure to early atherosclerosis. The Bogalusa Heart Study. N Engl J Med. 1986; 314: 138144

5) McGill HC, Jr., McMahan CA, Malcom GT, Oalmann MC and Strong JP. Effects of serum lipoproteins and smoking on atherosclerosis in young men and women. The PDAY Research Group. Pathobiological Determinants of Atherosclerosis in Youth. Arterioscler Thromb Vasc Biol. 1997; 17: 95-106
6) Kusters DM, Wiegman A, Kastelein JJ and Hutten BA. Carotid intima-media thickness in children with familial hypercholesterolemia. Circ Res. 2014; 114: 307-310

7) Vuorio A, Docherty KF, Humphries SE, Kuoppala J and Kovanen PT. Statin treatment of children with familial hypercholesterolemia--trying to balance incomplete evidence of long-term safety and clinical accountability: are we approaching a consensus? Atherosclerosis. 2013; 226: 315-320

8) National Cholesterol Education Program (NCEP): highlights of the report of the Expert Panel on Blood Cholesterol Levels in Children and Adolescents. Pediatrics. 1992; 89: 495-501

9) Harada-Shiba M, Arai H, Oikawa S, Ohta T, Okada T, Okamura T, Nohara A, Bujo H, Yokote K, Wakatsuki A, Ishibashi $S$ and Yamashita $S$. Guidelines for the management of familial hypercholesterolemia. J Atheroscler Thromb. 2012; 19: 1043-1060

10) Teramoto T, Sasaki J, Ishibashi S, Birou S, Daida H, Dohi $S$, Egusa $G$, Hiro $T$, Hirobe $K$, Iida $M$, Kihara $S$, Kinoshita M, Maruyama C, Ohta T, Okamura T, Yamashita S, Yokode M, Yokote K, Japan Atherosclerosis Society Committee for E and Clinical Management of A. Diagnosis of atherosclerosis. Executive Summary of the Japan Atherosclerosis Society (JAS) Guidelines for the Diagnosis and Prevention of Atherosclerotic Cardiovascular Diseases in Japan-2012 Version. J Atheroscler Thromb. 2014; 21: 296-298

11) Kavey RE, Allada V, Daniels SR, Hayman LL, McCrindle BW, Newburger JW, Parekh RS, Steinberger J, American Heart Association Expert Panel on P, Prevention S, American Heart Association Council on Cardiovascular Disease in the Y, American Heart Association Council on E, Prevention, American Heart Association Council on Nutrition PA, Metabolism, American Heart Association Council on High Blood Pressure R, American Heart Association Council on Cardiovascular N, American Heart Association Council on the Kidney in Heart D, Interdisciplinary Working Group on Quality of C and Outcomes R. Cardiovascular risk reduction in high-risk pediatric patients: a scientific statement from the American Heart Association Expert Panel on Population and Prevention Science; the Councils on Cardiovascular Disease in the Young, Epidemiology and Prevention, Nutrition, Physical Activity and Metabolism, High Blood Pressure Research, Cardiovascular Nursing, and the Kidney in Heart Disease; and the Interdisciplinary Working Group on Quality of Care and Outcomes Research: endorsed by the American Academy of Pediatrics. Circulation. 2006; 114: 27102738

12) Harada-Shiba M, Arisaka O, Ohtake A, Okada T, Suganami $\mathrm{H}$ and group N-Psr. Efficacy and Safety of Pitavastatin in Japanese Male Children with Familial Hypercholesterolemia. J Atheroscler Thromb. 2016; 23: 48-55

13) Vuorio A, Kuoppala J, Kovanen PT, Humphries SE, Tonstad S, Wiegman A and Drogari E. Statins for children with familial hypercholesterolemia. Cochrane Database Syst Rev. 2014; 7: CD006401

14) Bateman BT, Hernandez-Diaz S, Fischer MA, Seely EW, Ecker JL, Franklin JM, Desai RJ, Allen-Coleman C, 
Mogun H, Avorn J and Huybrechts KF. Statins and congenital malformations: cohort study. BMJ. 2015; 350: h1035

15) Wiegman A, Gidding SS, Watts GF, Chapman MJ, Ginsberg HN, Cuchel M, Ose L, Averna M, Boileau C, Boren J, Bruckert E, Catapano AL, Defesche JC, Descamps OS, Hegele RA, Hovingh GK, Humphries SE, Kovanen PT, Kuivenhoven JA, Masana L, Nordestgaard BG, Pajukanta P, Parhofer KG, Raal FJ, Ray KK, Santos RD, Stalenhoef AF, Steinhagen-Thiessen E, Stroes ES, Taskinen MR, Tybjaerg-Hansen A, Wiklund O and European Atherosclerosis Society Consensus P. Familial hypercholesterolaemia in children and adolescents: gaining decades of life by optimizing detection and treatment. Eur Heart J. 2015

16) Wilmot KA, O'Flaherty M, Capewell S, Ford ES and Vaccarino V. Coronary Heart Disease Mortality Declines in the United States From 1979 Through 2011: Evidence for Stagnation in Young Adults, Especially Women. Circulation. 2015

17) Kusters DM, Avis HJ, de Groot E, Wijburg FA, Kastelein JJ, Wiegman A and Hutten BA. Ten-year follow-up after initiation of statin therapy in children with familial hypercholesterolemia. JAMA. 2014; 312: 1055-1057

18) McCrindle BW, Urbina EM, Dennison BA, Jacobson MS, Steinberger J, Rocchini AP, Hayman LL, Daniels SR, American Heart Association Atherosclerosis H, Obesity in Youth C, American Heart Association Council of Cardiovascular Disease in the $\mathrm{Y}$ and American Heart Association Council on Cardiovascular N. Drug therapy of high-risk lipid abnormalities in children and adolescents: a scientific statement from the American Heart Association Atherosclerosis, Hypertension, and Obesity in Youth Committee, Council of Cardiovascular Disease in the Young, with the Council on Cardiovascular Nursing. Circulation. 2007; 115: 1948-1967

19) Daniels SR, Greer FR and Committee on N. Lipid screening and cardiovascular health in childhood. Pediatrics. 2008; 122: 198-208

20) Identification and Management of Familial Hypercholesterolaemia (FH) London; 2008

21) Watts GF, Sullivan DR, Poplawski N, van Bockxmeer F, Hamilton-Craig I, Clifton PM, O'Brien R, Bishop W, George P, Barter PJ, Bates T, Burnett JR, Coakley J, Davidson P, Emery J, Martin A, Farid W, Freeman L, Geelhoed E, Juniper A, Kidd A, Kostner K, Krass I, Livingston M, Maxwell S, O'Leary P, Owaimrin A, Redgrave TG, Reid N, Southwell L, Suthers G, Tonkin A, Towler S, Trent R and Familial Hypercholesterolaemia Australasia Network Consensus G. Familial hypercholesterolaemia: a model of care for Australasia. Atheroscler Suppl. 2011; 12: 221-263

22) Expert Panel on Integrated Guidelines for Cardiovascular $\mathrm{H}$, Risk Reduction in C, Adolescents, National Heart L and Blood I. Expert panel on integrated guidelines for cardiovascular health and risk reduction in children and adolescents: summary report. Pediatrics. 2011; 128 Suppl 5: S213-256

23) Goldberg AC, Hopkins PN, Toth PP, Ballantyne CM, Rader DJ, Robinson JG, Daniels SR, Gidding SS, de Ferranti SD, Ito MK, McGowan MP, Moriarty PM, Cromwell WC, Ross JL and Ziajka PE. Familial hypercholesterolemia: screening, diagnosis and management of pediatric and adult patients: clinical guidance from the National Lipid Association Expert Panel on Familial Hypercholesterolemia. J Clin Lipidol. 2011; 5: 133-140 